\title{
Realizing Multiple Benefits in U.S. Army Corps of Engineers (USACE) Baltimore District Dredging Projects through Application of Engineering With Nature ${ }^{\circledR}$ Principles
}

By Danielle M. Szimanski, Andrew D. McQueen, and Burton C. Suedel

PURPOSE: The application of Engineering With Nature ${ }^{\circledR}(E W N)$ principles at existing U.S. Army Corps of Engineers (USACE) dredging and navigation projects is increasing. This technical note $(\mathrm{TN})$ documents four USACE Baltimore District (NAB) projects that successfully applied EWN principles.

BACKGROUND: Advancing best practices within the USACE involves identifying actions that can be taken to better align and integrate engineering and natural systems to produce more socially acceptable, economically viable, and environmentally sustainable projects. EWN is a USACE initiative that supports more sustainable practices, projects, and outcomes by working to intentionally align natural and engineering processes to efficiently and sustainably deliver economic, environmental and social benefits through collaborative processes (Bridges et al. 2014; Gerhardt-Smith and Banks 2014). The EWN initiative focuses on developing practical methods to provide an ecosystem approach to navigation infrastructure development and operations that is applicable across multiple USACE missions and business lines. Projects demonstrating EWN principles illustrate the use of science and engineering to maximize natural processes to produce practical operational efficiencies that support substantiated economic, social, and environmental benefits while continuing to meet project needs. A critical aspect of EWN is science-based collaborative processes to organize and focus interests, stakeholders, and partners to produce more broadly acceptable projects (www.engineeringwithnature.org).

Developing sustainable and resilient infrastructure requires the USACE to apply new approaches to engineering and operating infrastructure. The EWN program is developing and demonstrating, through multiple projects, the capabilities that are needed to achieve sustainable project outcomes. The following project case studies are presented to illustrate the types of dredging and navigation projects that were completed by NAB that exemplify EWN principles.

CASE STUDIES: The following four projects are examples of how NAB is incorporating EWN in dredging and navigation projects. Each of these projects demonstrates the added benefits (economic, environmental, and social) that can be achieved from forward thinking, planning, and collaboration to maximize the success of dredging projects. The authors met in August 2017 to compile information from project files and fact sheets to document how each project incorporated EWN principles. 
Isle of Wight Bay Restoration Project, Worcester County, MD. The Isle of Wight Bay restoration project began with the dredging of the Isle of Wight Federal channel by the NAB and the subsequent beneficial use of the sediments dredged from the channel. The primary objective of the strategic placement of the Isle of Wight channel sediments was to restore salt marsh habitat through the use of strategically placed dredged material and construction of rubble mound breakwaters. The shoreline had eroded at this location, exposing built infrastructure through the loss of marsh habitat in the area.

The Isle of Wight Federal channel is a three mile navigation channel that is six feet (ft) deep and $75 \mathrm{ft}$ wide that extends into the Isle of Wight Bay. Dredged material was hydraulically pumped with a diffuser behind breakwaters to create a bayside and upland marsh. The marsh was planted with the following three varieties of vegetation: Poa pratensi (bluegrass), Festuca rubra (red fescue), and Spartina alterniflora (smooth cordgrass). On the western side of the restored marsh, an opening in the breakwater was created to allow for tidal flows into and out of the marsh. The opening allows for natural water flows that sculpt the marsh (Figures 1-3). Additionally, a handicap accessible pier was constructed, providing the public with recreational fishing and crabbing opportunities (Figure 1, bottom).

The benefits of the project include abatement of eroding shoreline, creation and restoration of coastal marsh habitat, and creation of recreational opportunities via the construction of the pier. This project allowed for the restoration of the Isle of Wight to its historical 1850 footprint, and included the creation of a salt marsh that provides critical habitat for fish, crabs, and waterfowl (Figure 2). In total, the project restored 4.6 acres of low marsh and 1.9 acres of high marsh (6.5 acres total) that extends approximately $325 \mathrm{ft}$ from the existing shoreline (Figure 1).

Collaborations essential to the success of the project included coordination with the Maryland Department of Natural Resources (MDNR), Worcester County, MD, and the U.S. Fish and Wildlife Service (USFWS). This project exemplified EWN principles through collaborative stakeholder communications and added ecological, economic, and social benefits which were achieved through the use of strategically placed dredged material at no additional cost relative to traditional confined placement. 


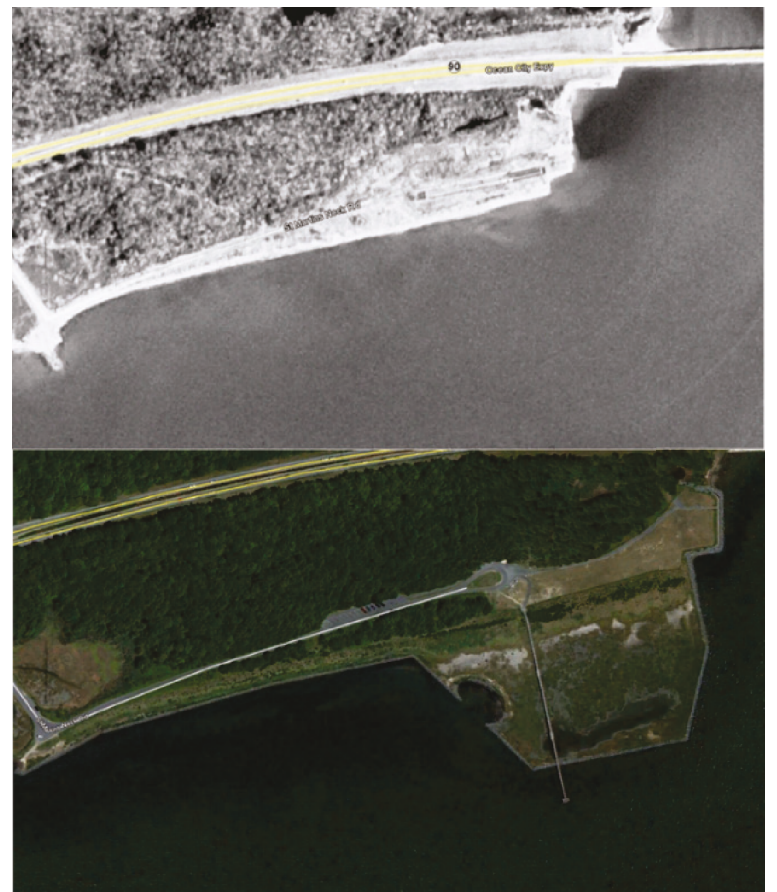

Figure 1. Isle of Wight before dredged material placement. Top: historic 1989 aereal image. Bottom: after dredge material placement and marsh establishment 2017 aereal image. (Images sourced from Google, DigitalGlobe 2017).

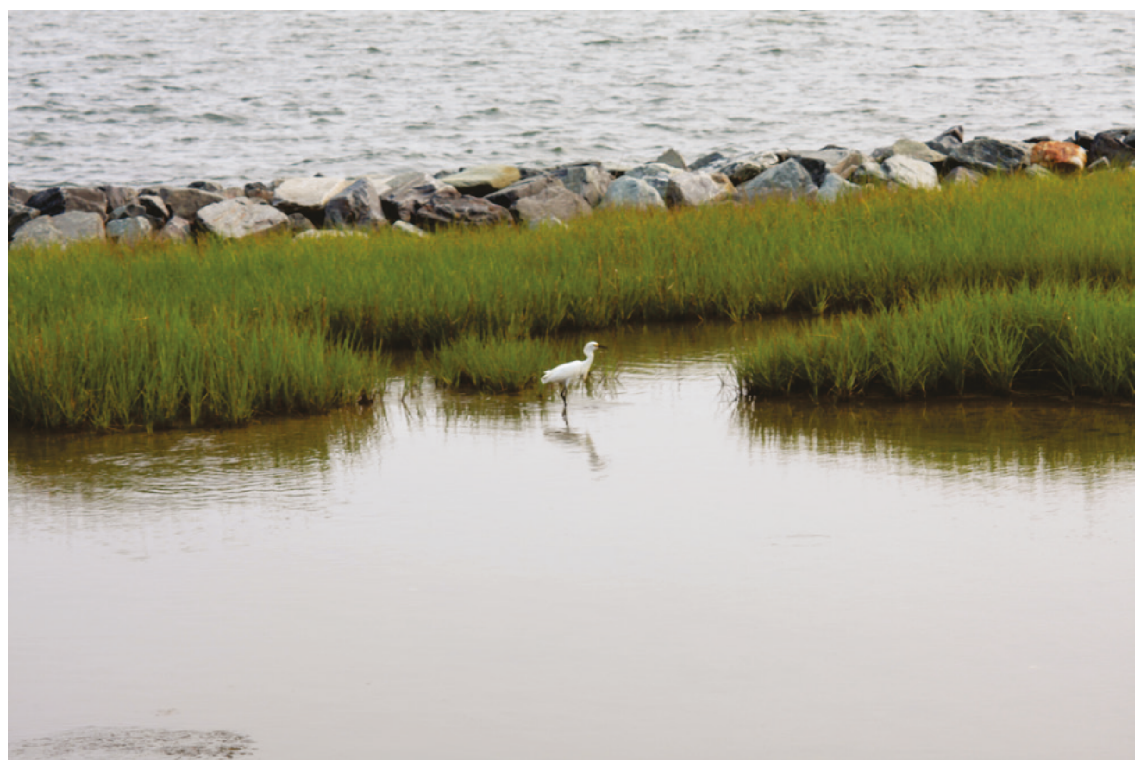

Figure 2. Wading birds utilize the restored Isle of Wight salt marsh. 


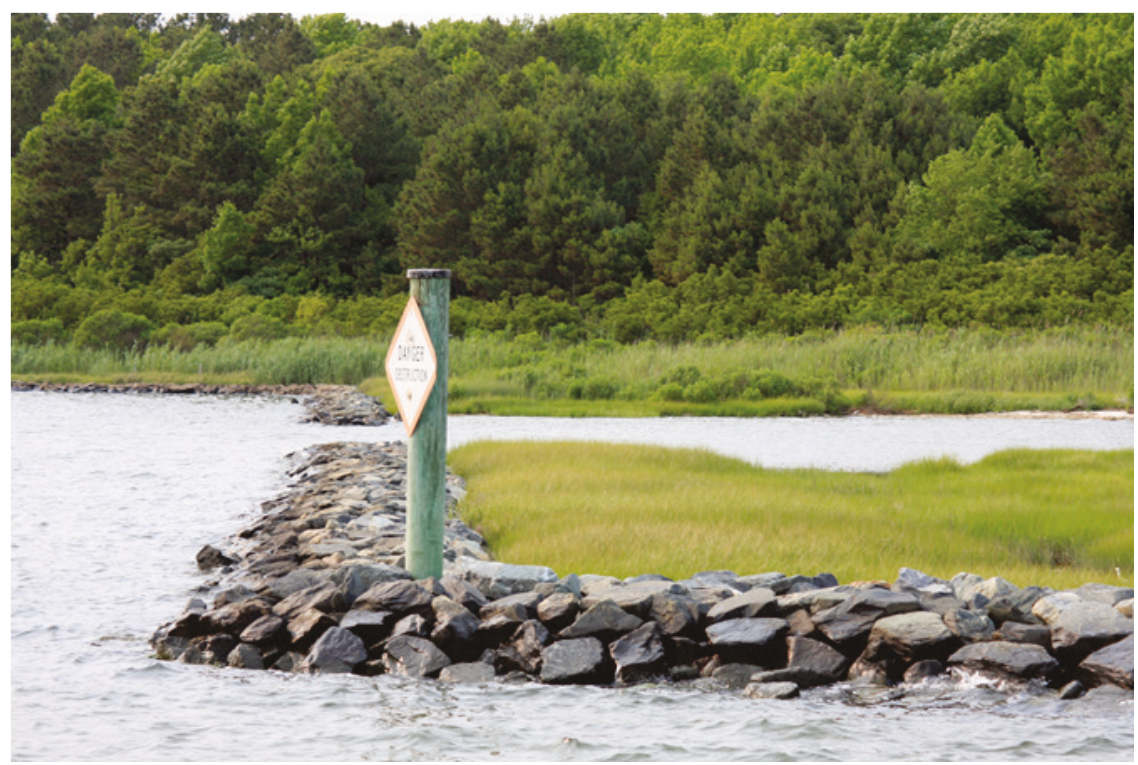

Figure 3. The opening created in the Isle of Wight breakwater allowing for natural tidal flows within the marsh.

Barren Island Restoration, Dorchester County, MD. The Barren Island restoration project received sediment via dredging of the Honga River and Tar Bay Federal channels by NAB. The primary objective of the Barren Island restoration project was abatement of barrier island erosion through breakwater construction and restoration of marsh habitat through beneficial use of dredged material. Barren Island is a USFWS owned barrier island in the Chesapeake Bay which provides shoreline erosion protection to the mainland of Dorchester County and critical mash habitat for migratory waterfowl. In 2004, sediment dredged from the Honga River and Tar Bay federal channels was hydraulically pumped with a diffuser behind constructed rubble mound breakwaters to create a salt marsh on the northern section of the island (Figure 4). In a separate dredging contract in 2008, segmented rubble mound breakwaters were constructed on the western side of the island to permit full tidal flows to help restore recently lost marsh habitat. The dredged material was pumped behind the breakwater to a height that created low marsh and high marsh habitat.

The USACE contracted plantings to help ensure sediment stability, erosion control, marsh habitat colonization, and to prevent invasive species (e.g., Phragmities spp.) colonization and establishment. The restored north shoreline was vegetated with approximately 150,000 plants consisting of a variety of wetland species (Spartina alternaflora [100,000]; Spartina patens [30,000]; Juncus spp. [10,000]; Distichlis spp. [10,000]) (Figure 5). Following establishment of planted wetland species, aerial waterfowl surveys were conducted by USFWS to quantify the utilization of the restored habitat by a diversity of waterfowl post-restoration. In recent years, the abundance and diversity of waterfowl populations utilizing the Barren Island marsh have increased compared to counts made in 2015 , with seven species totaling over 6,400 individuals observed during a winter 2016 survey conducted by the USFWS. 


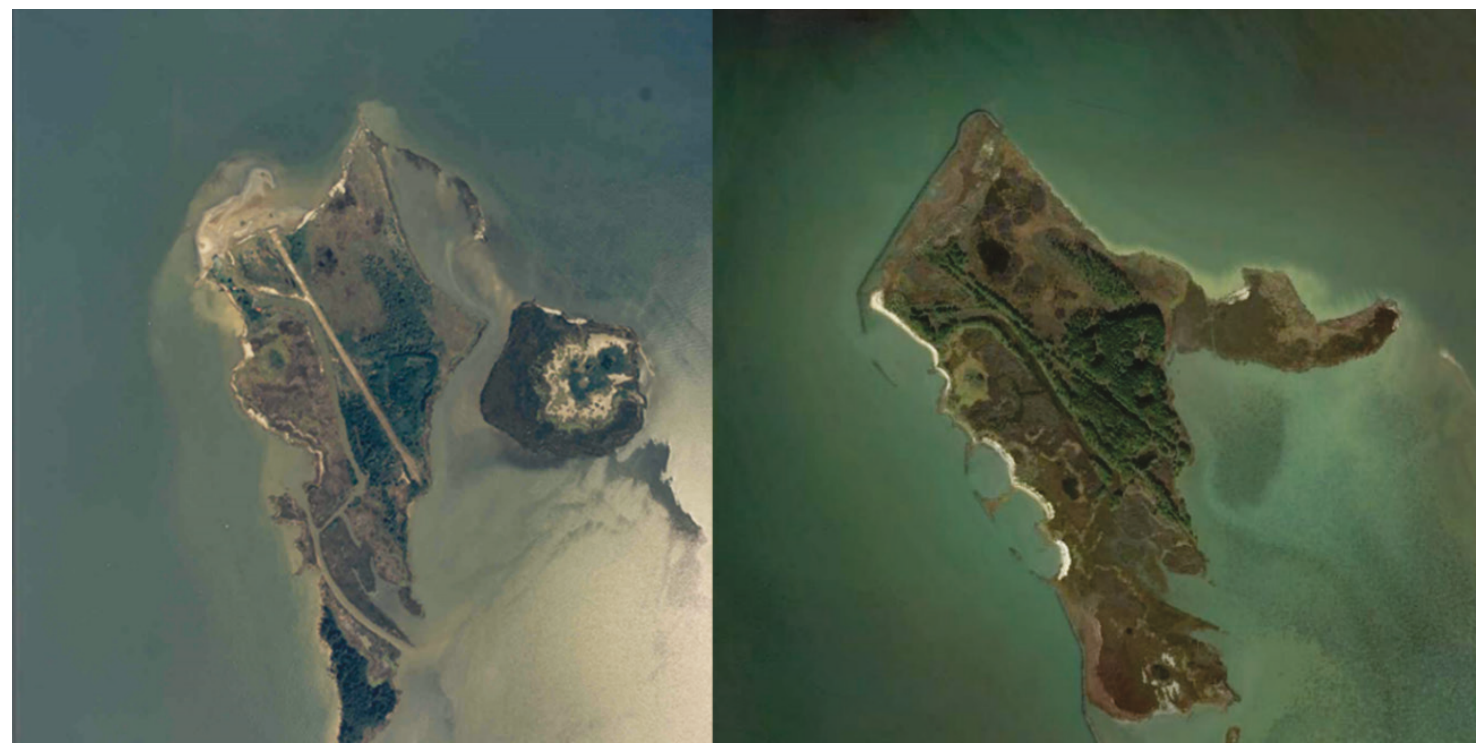

Figure 4. Barren Island before (left) and after (right) construction of breakwaters and restored marsh habitat (Images sourced from Google, DigitalGlobe 2017).

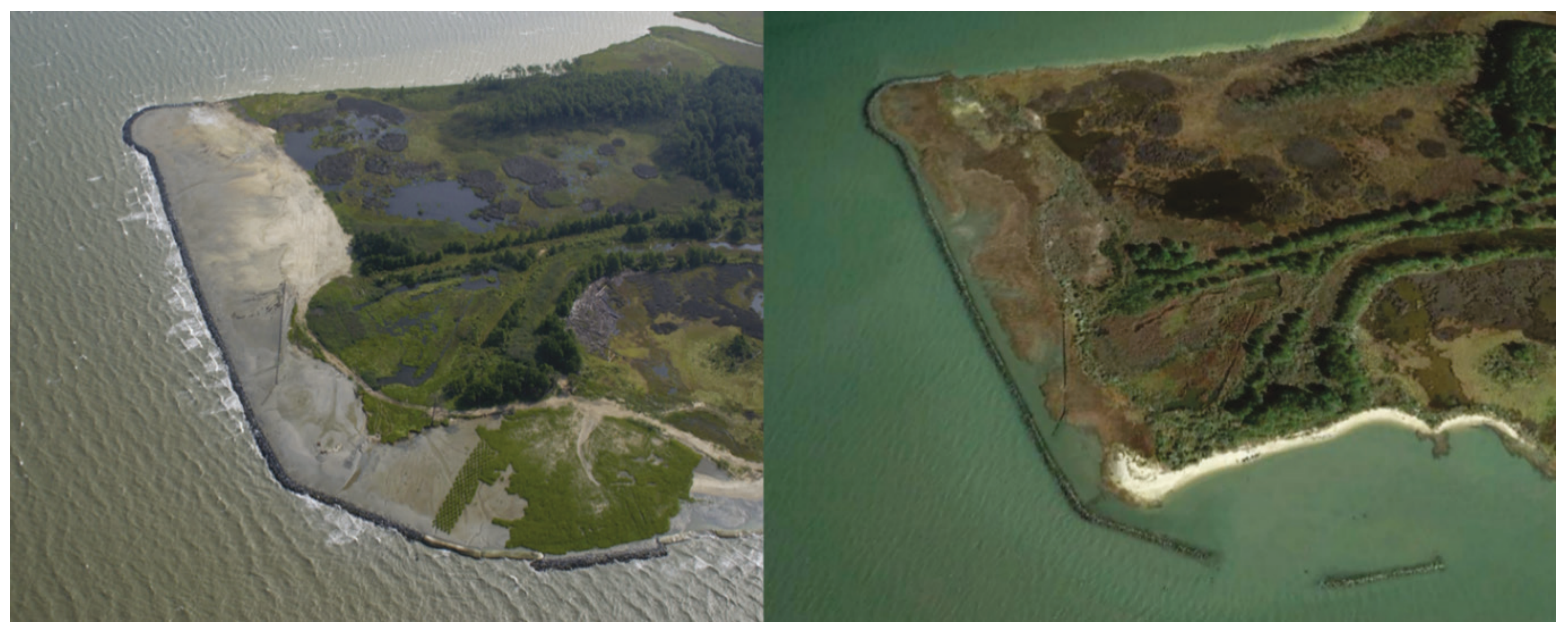

Figure 5. Barren Island north shore restoration before (left) and after (right) wetland plantings.

The benefits of the project included abatement of eroding shoreline, creation and restoration of coastal marsh habitat, and providing additional erosion protection to the adjacent Hooper Island and associated built infrastructure from storm events in Chesapeake Bay. Consistent with EWN, segmented breakwaters along the west side of Barren Island were designed and built to permit full tidal flows and to minimize the influence of overtopping and tidal flushing associated with continuous breakwaters (Figure 6). Operational efficiencies of material dredged from the adjacent Honga River and Tar Bay federal channels minimized operational costs as compared to the traditional upland placement alternative. Essential to the success of the project was the collaboration with USFWS and Dorchester County for selection of wetland plant species and postrestoration monitoring. 


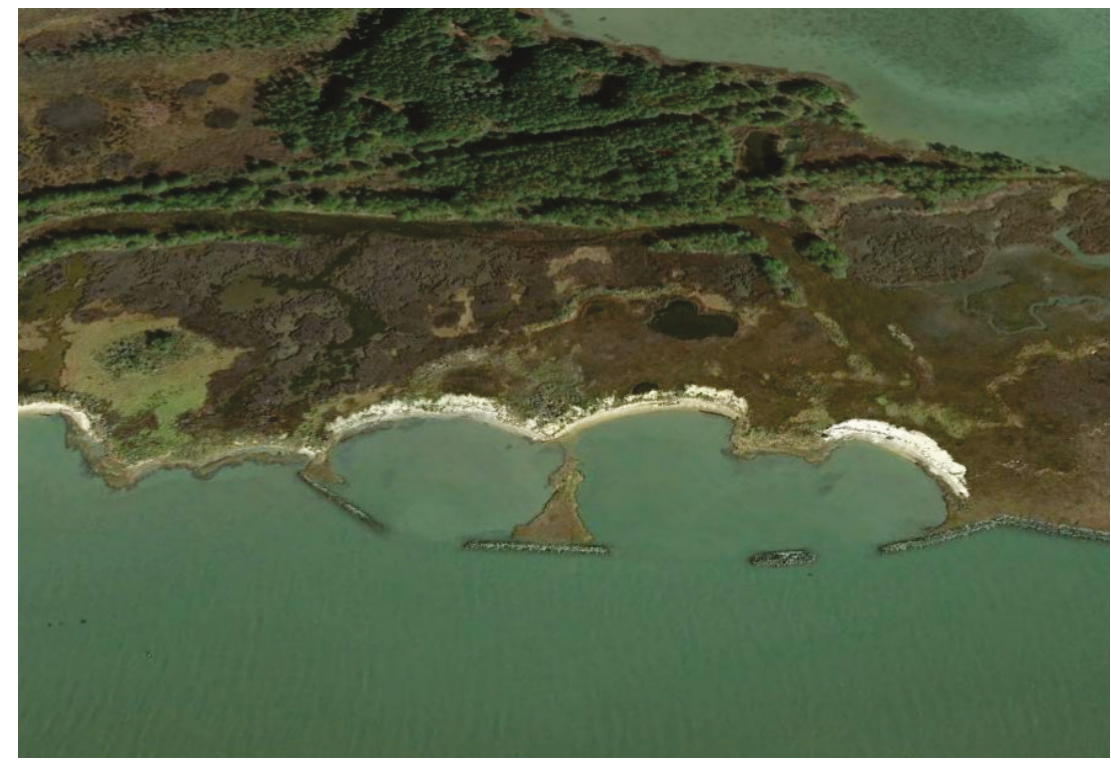

Figure 6. Barren Island segmented breakwaters designed and constructed to promote natural tidal flows to stabilize coastal marsh habitat (Images sourced from Google, DigitalGlobe 2017).

Battery Island Restoration, Harford County, MD. The primary objective of the Battery Island restoration project was to beneficially use dredged material to restore an eroded waterfowl nesting site and historic lighthouse in the Susquehanna National Wildlife Refuge. Battery Island is located in a high energy system near the Susquehanna Flats where the Susquehanna River meets the Chesapeake Bay, just south of the Conowingo Dam. Material was dredged from the Susquehanna federal channel at the mouth of the Susquehanna River as it empties into the Chesapeake Bay next to the city of Havre De Grace. Dredged material was placed hydraulically with a diffuser and distributed by earth moving equipment to create an unconfined horseshoeshaped island (Figure 7). This innovative use of dredged material applies EWN principles and was cost-competitive with traditional upland confined placement alternatives.

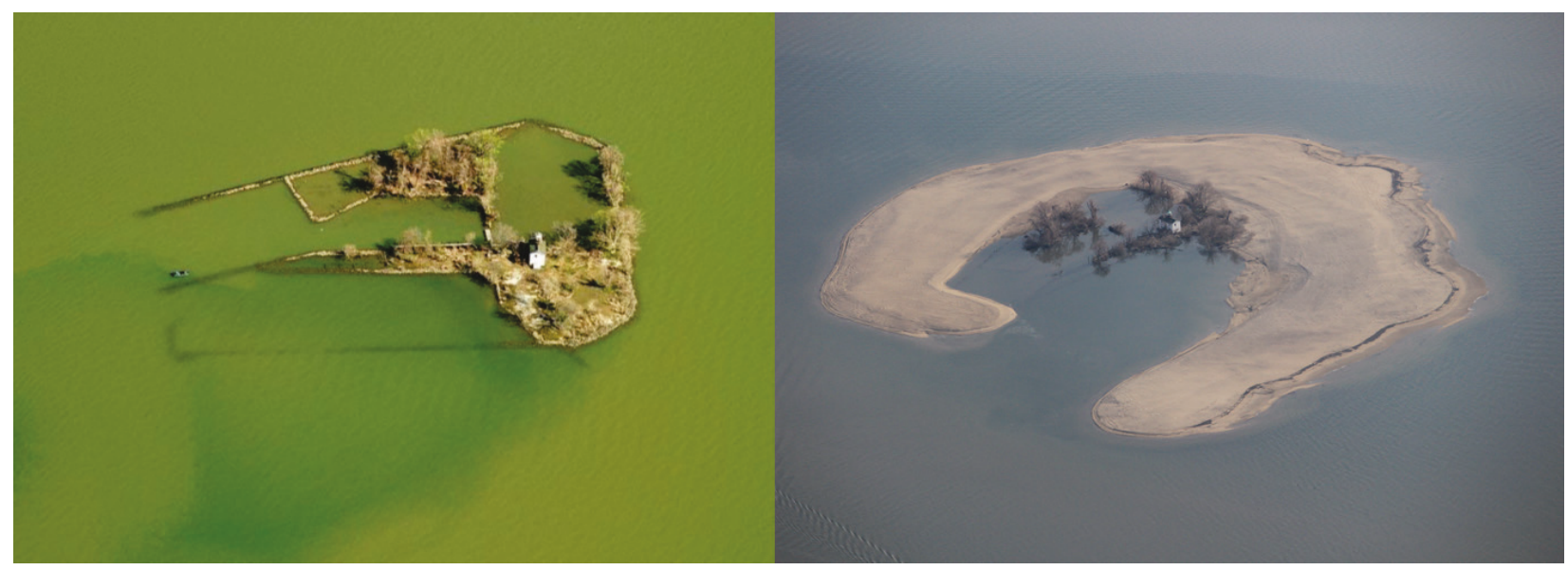

Figure 7. Battery Island before (left; 2011) and after (right; 2013) unconfined placement of dredge material. 
The island was restored to approximately 11 acres (above water) to support American black duck (Anas rubripes) and Caspian tern (Hydroprogne caspia) habitat, and to prevent the flooding of the historic Fishing Battery Lighthouse. Habitats restored were tidal marsh, intertidal marsh, high marsh, upland and submerged aquatic vegetation (SAV) that could support a variety of species. About 60,000 native plants were planted by USACE contractors (Figure 8) to encourage establishment of native vegetation and to minimize establishment of invasive species (e.g., Phragmities spp.). Planted species included the following: Peltandra virginica, Scirpus pungens, Schoenoplectus tabernaemontanii, and Caphalanthus occidentals in the tidal marsh area; Panicum virgatum, Schizachyrum scoparium, Solidago sempervirens, and Baccharis halmifolia in the marsh transition area; Morella pensylvanica, Campsis radicans, and Rhus romatica in the upland area; and Spartinal alterniflora on the outside slope.

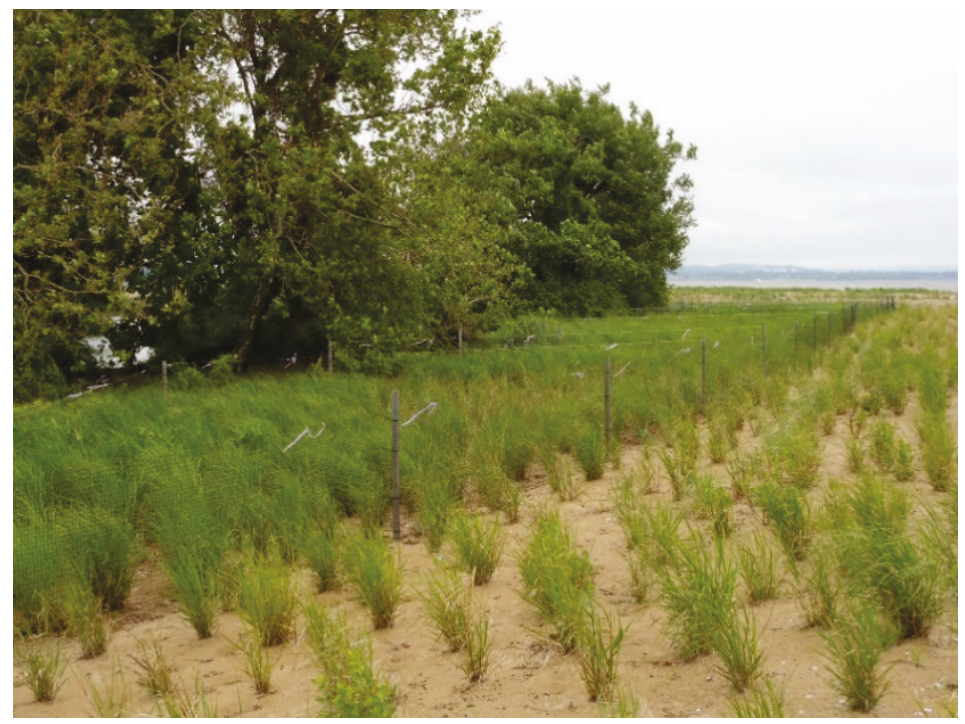

Figure 8. Battery Island upland plant habitat restored following planting activities.

Benefits of the project included island restoration, marsh habitat creation, and erosion control. The strategic placement of sandy dredged material was unconfined to allow for island self-forming and establishment of SAV beds in the opening designed in the island's shape, reflecting wind and fetch patterns from Chesapeake Bay. The SAV areas provide one of the most important ecosystem services in the Chesapeake Bay area, providing habitat for juvenile and adult fish and shellfish, food for waterfowl, and stabilizing bottom sediments. An additional benefit of the project was the preservation of the historic Fishing Battery Lighthouse that was originally constructed in 1851 (Figure 9). The lighthouse was threatened following the erosion of the island to less than 1 acre prior to the habitat restoration. The city of Havre de Grace has plans to restore the lighthouse in the future. The direction and placement of the open cove area of the island (Figure 7, right) was based on stakeholder input and is helping reduce erosion of the island. The USFWS, National Park Service, MDNR, Maryland Department of the Environment (MDE), City of Havre de Grace, and Hartford County, MD coordinated on the design and footprint of the island and the wetland species to be planted. 


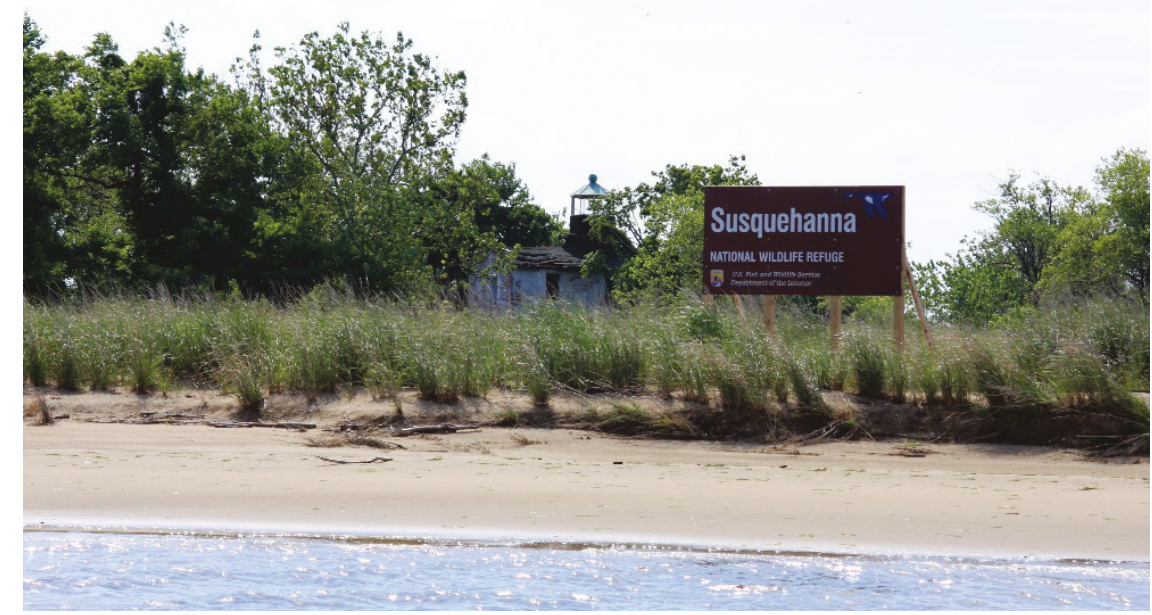

Figure 9. Fishing Battery Lighthouse on the island was preserved following the strategic placement of dredged material, which enlarged the island's footprint to 11 acres.

Mark-12 Island Restoration, Worcester Co., MD. The primary objective of the Mark-12 Island restoration project was to restore a back bay island of Sinepuxent Bay, which had been completely eroded since the 1930s, through the use of strategically placed dredged material. Sandy dredged material, sourced from the Sinepuxent Bay navigation channel located near Assateague Island and Ocean City, MD, was used to restore the eroded island habitat. The dredged material was placed in an unconfined manner, allowing wind and waves to self-form the island and for the colonization of native vegetative propagules, to serve as valuable wildlife habitat (Figure 10).

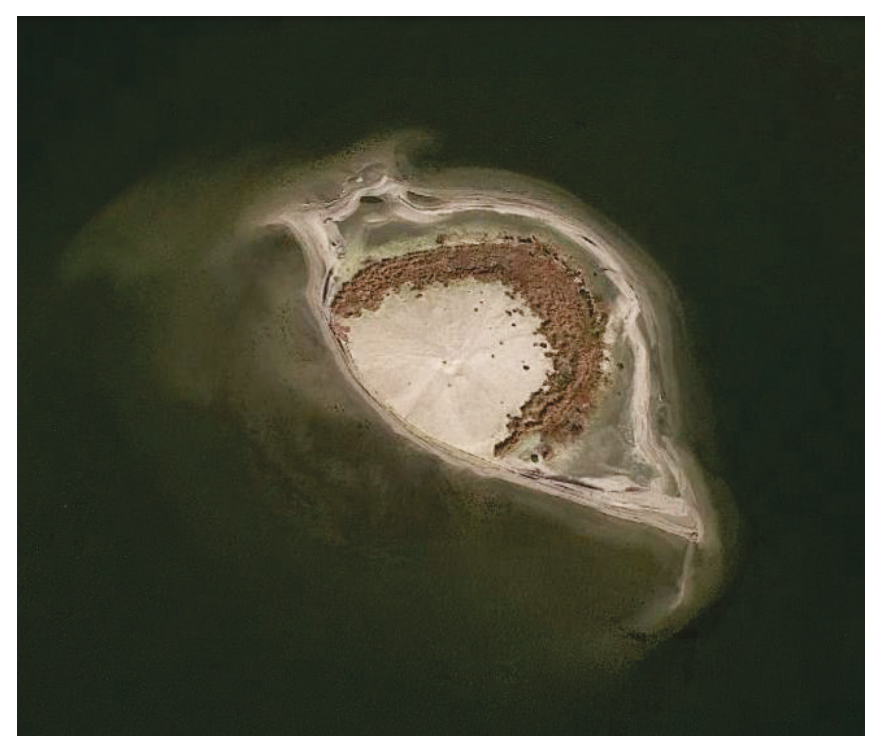

Figure 10. Mark-12 island and surrounding mudflat created using unconfined open water placement of dredge material two years post construction (2017 images sourced from Google, DigitalGlobe 2017). 
In coordination with the USFWS, qualitative monitoring provided information of the ecosystem service benefits following island restoration. The self-formed island provides habitat for migratory birds, including common terns (Sterna hirundo), an endangered species in MD. In addition, the strategic placement of material created shallow mudflats that provided habitat and spawning areas for summer and winter flounder (Pseudopleuronectes spp.) and horseshoe crabs (Limulus spp.). In addition to the Mark-12 Island, three other islands (Mark-14, Tern Island, and Robins Marsh) were created in Sinepuxent and Isle of Wight Bays in a similar manner, beneficially using dredged material from the adjacent federal channels to restore coastal island migratory bird habitat. Collaboration with the Assateague Island National Park Service, MDNR, the Town of Ocean City, and USFWS were critical to the success of the project for identification of critical habitat(s) in Sinepuxent Bay and post-restoration monitoring.

SUMMARY: This (TN) summarizes NAB dredging projects which successfully applied EWN principles. As such examples, the Isle of Wight Bay project utilized effective collaborative stakeholder communications, the Barren Island project utilized segmented breakwaters to permit full tidal flows and minimize the overtopping and tidal flushing to restore marsh at no added cost, the project at Battery Island restored marsh habitat and preserved a historic landmark through the strategic placement of dredged material, allowing the island to self-form, all through an effective stakeholder engagement process, and the Mark 12 island project utilized effective stakeholder engagement and collaboration to aid the design of this self-forming island for maximizing migratory bird habitat. These NAB projects demonstrate that more sustainable practices and outcomes can be achieved by working to intentionally align natural and engineering processes to efficiently and sustainably deliver economic, environmental, and social benefits through collaborative processes. Broadening the communication of these projects in the Chesapeake Bay region fosters their integration into USACE business practices of project design to more effectively manage the nation's waterways.

POINT OF CONTACT: For additional information, contact Dr. Burton Suedel (601-634-4578, Burton.Suedel@usace.army.mil) or Danielle Szimanski (410-962-6064; Danielle.m.szimanski @usace.army.mil). This TN should be cited as follows:

Szimanski, D. M., A. D. McQueen, and B. C. Suedel. 2019. Engineering With Nature Projects in the USACE Baltimore District. EWN Technical Notes Collection. ERDC/TN EWN-19-3. Vicksburg, MS: U.S. Army Engineer Research and Development Center. http://el.erdc.usace.army.mil/.

\section{REFERENCES}

Bridges, T. S., J. Lillycrop, J. R. Wilson, J. T. Fredette, B. C. Suedel, C. J. Banks, and E. J. Russo. 2014. Engineering With Nature promotes triple-win outcomes. Terra et Aqua 135:17-23. https://www2.iadc-dredging.com/wpcontent/uploads/2017/02/article-engineering-with-nature-promotes-triple-win-outcomes-135-2.pdf.

Gerhardt-Smith, J. M., and C. J. Banks. 2014. USACE Regional Sediment Management and Engineering with Nature 2013 Workshop Summary. ERDC TN-EWN-14-3. Vicksburg, MS: U.S. Army Engineer Research and Development Center. 